Agro-Science Journal of Tropical Agriculture, Food, Environment and Extension Volume 18 Number 3 (September 2019) pp. 29-34

ISSN 1119-7455

\title{
WILLINGNESS OF SNAIL CONSUMERS TO CHOOSE SNAIL PRODUCTION AS LIVELIHOODS IN IBADAN SOUTHWEST LOCAL GOVERNMENT AREA OF OYO STATE, NIGERIA
}

\author{
*Aromolaran A.K., Alarima C.I., Awotunde J.M. and Olatunde O.A. \\ Department of Agricultural Extension \& Rural Development, \\ Federal University of Agriculture, Abeokuta, Ogun State, Nigeria \\ *Corresponding author's email: garomolaran@yahoo.com
}

\begin{abstract}
Snails are common in the rainforest region especially during the rainy season, but its population in the wild is decreasing due to human and environmental activities. This affect quantity available for consumption and it prompts the reason to encourage snail production. The study examined snail consumer's willingness to choose snail production as means of livelihoods. Snowball sampling technique was used to select 120 consumers. Data were obtained through questionnaires and analysed using descriptive and correlation analyses. The result shows that many $(60 \%)$ of the respondents were male, $48.7 \%$ were married with an

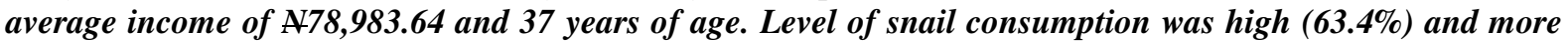
than 50\% were willing to choose snail production as a means of livelihood. Meanwhile, poor supply of feeding materials (43.5\%) and inadequate skills in snail rearing (39.1\%) were perceived as major constraints. Correlation result shows significant relationship between age $(r=0.346, p<0.05)$, level of snail consumption $(r=0.200, p<0.05)$ and willingness to choose snail production as means of livelihoods. The study concluded that people that consume more snails were willing to choose snail production. It is recommended that concerned agencies for capacity building should consider training people especially snail consumers in snail production and provide palliative resources to overcome challenges in snail production for sustainability and transformation of the agricultural system.
\end{abstract}

Key words: consumers, willingness to choose, snail production, constraints and livelihoods

\section{INTRODUCTION}

Snail is a common name for almost all members of the Mollusca class Gastropoda that have coiled shells in the adult stage, they have soft-bodied, unsegmented animals, with a body organized into a muscular foot, a head, a visceral mass containing most of the organ systems, and a fleshy mantle that secretes the calcareous shell (Pyron and Brown 2015). The phylum Mollusca has about 100,000 described species and potentially 100,000 species yet to be described (Strong et al., 2008).The snail entire body is made up of the shell which constitutes almost $22-24 \%$, the edible portion is about $22-23 \%$, and the liquid, called haemolymph makes up the remaining part of the body (Kehinde et al., 2009; Omole et al., 2011). Snail is a vital source of human food and its products have high nutritional value (Tremlova, 2001), containing food energy, high quality proteins, vitamins and minerals. Snail meat has been consumed by humans worldwide since pre-historic times (Cobbinah et al., 2008). The consumption of snail globally is $400.000-450.000$ tons per annum, but only $15 \%$ comes from the breeding of snail, while the remaining $85 \%$ are from snails collected from nature (Aristotle University of Thessaloniki, 2013). Italians ate an estimated 40,000 tons of in 2014, ahead of France with annual consumption of around 30,000 tons (Parternostro and Ide, 2015). In most of the West Africa countries especially in the forest region, eating of the snail is common and it is part of their many dishes. African giant snail (Archachatina marginata) is the most common snail found and eaten in Nigeria. Environmental factors such as deforestation, increased temperatures with low rainfall, slash and burning (bush fires), uncontrollable collection from the wild, high use of agrochemicals and lack of training on intensive snail farming are all impediments to increase snail supply both from the wild and in captivity in order to solve increasing demand for snail (Ngenwi et al., 2010). The survival of molluscs among other factors depends on climate change. Ejidike et al. (2004) opined that land snails prefer humid environments for optimum performance in the presence of their choice feed. Snail is a good source of vitamins $\mathrm{A}, \mathrm{B}_{6}, \mathrm{E}$ and $\mathrm{K}$, which are required for proper utilization of primary

Please cite as: Aromolaran A.K., Alarima C.I., Awotunde J.M. and Olatunde O.A. (2019). Willingness of snail consumers to choose snail production as livelihoods in Ibadan Southwest Local Government Area of Oyo State, Nigeria. Agro-Science, 18 (3), 29-34. DOI: https://dx.doi.org/10.4314/as.v18i3.6 
nutrients such as carbohydrate, fat and oil. (Kehinde et al., 2009; Omole et al., 2011). Consumption of snail in Nigeria is affected by the price of snail. Due to the low level of snail supply, the price is high and only a few rich ones can buy. Recently, the demand for snail meat at present has been on the increase especially for African giant land snail which its demand outstrips its supply (Murphy, 2001; Ebenso, 2003).

An intensive production and management of land snail are important and inevitable in order to overcome threats facing the survival of snails. Since the demand for snail is increasing and the supply is reducing to be able to solve this challenge especially for the snail consumers, it will be required that snail should be reared in an intensive system by the people. The rearing of snail is not commonly practised in Nigeria despite the comparative ease with which it can be established when compared with other aspects of livestock production. The production of snails in the snailery is one of the strategies that can be used to tackle the reduction of snail in the wild to meet the increase in demand. The people that are more likely to suffer the scarcity of snail most are the snail consumers and there is a possibility that they will look for a way to obtain the quantity of snail required by them. To meet the demand for snail, it will require the willingness of the people to take snail production as livelihoods. If the people especially the snail consumers who will feel the scarcity of the snail more could take up snail production as livelihoods there is a possibility to increase the quantity of snail that will be available for consumption in the society. On this background, it is necessary to examine whether snail consumers will be willing to choose snail production as means of livelihoods. The study specifically determined the rate of snail consumption, willingness to engage in snail farming, and constraints to snail farming. It was also hypothesized that there is no significant relationship between socioeconomic characteristics, level of snail consumption of the consumers and their willingness to choose snail production as means of livelihoods.

\section{MATERIALS AND METHODS Description of Study Area}

Ibadan South West Local Government Area (LGA) was carved out by the government in 1991 . The administrative headquarter was at first in Town Planning in Oluyole Estates but now is in Aleshinloye. It covers a landmass of $244.55 \mathrm{~km}^{2}$ with a population of 283,098 persons. The 2010 estimated population was projected at 320,536 people using a growth rate of $3.2 \%$ from 2006 census (NPC, 2006). The area is bounded by Ibadan North West and Ido LGA in the west and Ibadan South East in the east. The local government is a home for small, medium, and large-scale industries. Many of the large-scale industries are located in Oluyole Estate. The local government covers Bere, Foko, Molete, Challenge, Ring Road, Anfani, Mokola, Vitas, Dugbe, Moor Plantation, Oluyole Estate, Odo-Ona, etc. It is dominated by Yorubas and other tribes who engage in different types of economic activities.

\section{Sampling Procedure and Data Collection}

A multistage sampling technique was used to select samples for the study. First, a simple random technique was used to select three wards out of the 12 wards in the LGA. From the 3 selected wards, four communities were randomly selected to make 12 communities. From the selected communities, snowballing method was used to choose 10 households, to make a total sample size of 120 snail consumers. The point of sale and restaurants were visited to obtain the initial respondent for the snowball method process in the study area. Primary data were used for this study and it was collected through the aids of questionnaires.

\section{Measurement of Variables}

- Rate of snail consumption was measured using six-point scale ranging from daily $=5$, weekly $=$ 4 , monthly $=3$, quarterly $=2$ and yearly $=1$. To obtain the different categories of snail consumption, the mean of the aggregated score was calculated. The mean score was used to categorise the consumption level into high and low. Those that had the mean score and above were rated as a high level of snail consumption and those that scored below the mean were regarded as low level of snail consumption which was used for further computation.

- Perceived constraints to snail farming were listed and measured using three-point scale major $=3$, minor $=2$, not at all $=1$.

- Willingness to choose snail production was measured with three-point scale willing $=3$, not sure $=2$, not willing $=1$.

Total score for each of the variables was computed and their mean was obtained to categorize each of the variables into a different level.

\section{Data Analysis}

Data were presented using descriptive statistics (mean, frequency count and percentage), while also analysed by correlations to test the hypothesis.

\section{RESULTS AND DISCUSSION}

Socio-Economic Characteristic of Respondents

Results presented in Table 1 shows that average age of the snail consumers was 36 years. This implies that respondents were young. Lawal and Oluyole (2008) had reported that age of farmers is one of the important determinants of adoption and that young farmers are more receptive than older ones as the older ones always want to stick with 
their old approaches than to uptake new ones. More than half $(60 \%)$ of the respondents were male. It is likely that the men folks are more snail eaters than the female and due to that it is possible to have many of them willing to engage in snail production. Men have a higher energy intake, and a higher percentage of the energy in men's diet is derived from animal products while women tend to consume vegetables more often (Bonomo et al. 2003, Kiefer et al., 2005, Prattala et al., 2006 Figueiredo et al., 2008). The average household size of snail consumers is six persons. Considering the size of the household, it is likely that there will be a quite number of people within the household that could influence themselves to take snail meat which can serve as an alternative source of protein in the rural communities. Most $(79.1 \%)$ of the snail consumers had a tertiary education which probably has given them more access to information that can enhance their understanding of the snail benefits. Level of education will not only encourage the people to consume snail but could also encourage them to raise the snail for sale to meet the demand of snail. The respondents made an average income of $\$ 78,983.64$ per annum. The income of the people could be one of the reasons why they will be willing to take up other livelihoods to generate more income for them. The people with low income may likely want to choose other livelihoods in order to generate more income for their survival. The people with higher income also might look for profiting livelihoods which they can invest their money to earn more income. This could prompt the interest of the respondents to choose snail production as livelihoods since they can make additional income from it.

\section{Level of Snail Consumption}

Entries in Figure 1 show the rate at which the consumers eat snail in the study area. Within a month $22 \%$ of the consumers eat snail at least once, while $27 \%$ consume snail weekly and $23 \%$ eat snail daily. The implication is that if a snail eater consumes one snail at least once a day, such consumer will have consumed 365 snails per year. Therefore, $23 \%$ daily snail consumers who eat one snail per day would have eaten more 10,000 snails per annum. This is without considering those that eat snail weekly, monthly and even yearly as well as eating more than one snail per time.

Figure 2 shows the further categorisation of the consumption into two groups - high and low levels. It indicates the number of snail consumers $(63 \%)$ that had a high consumption rate of snail. The implication is that more than half of the respondents consume many snails and it is likely that the scarcity of snail will affect their snail consumption in the study area. Due to their rate of
Table 1: Socio-economic characteristics of snail consumers

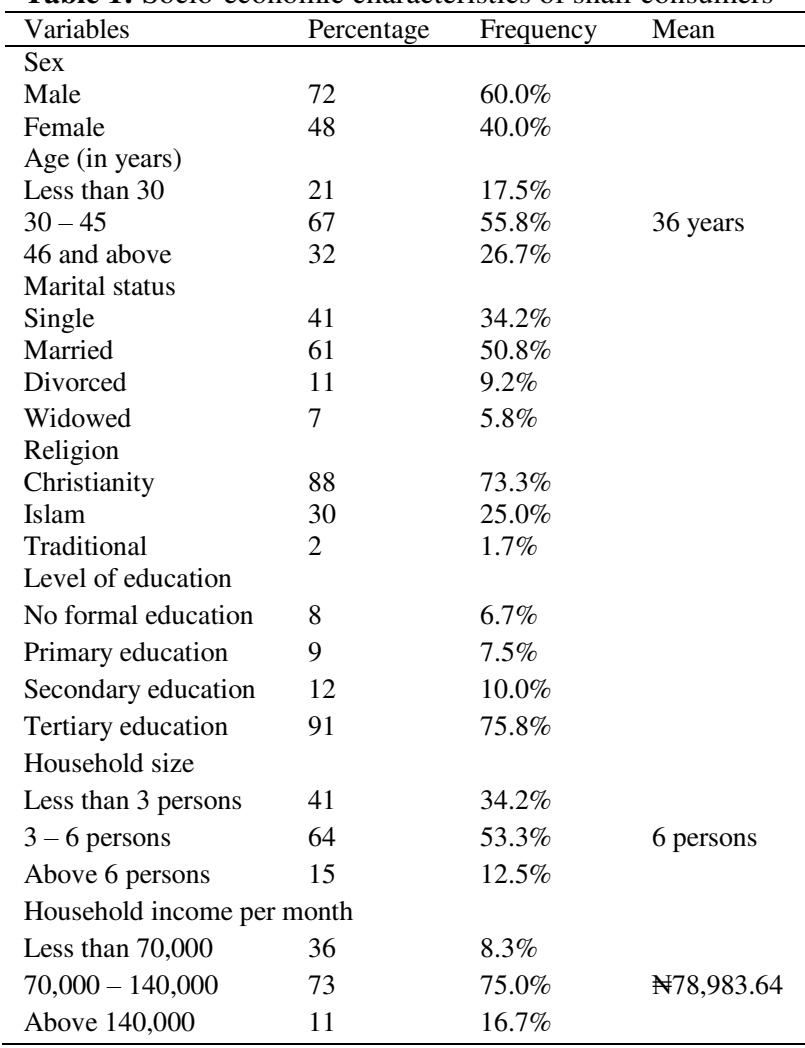

consumption and interest in the snail, there is a possibility that will support any activity that will ensure a continuous supply of snails. The higher snail consumers might be willing to take up the snail rearing as both means of obtaining snail quantity they need for consumption as well as for livelihoods to generate income.

\section{Willingness of Snail Consumers to Choose Snail Production as Livelihoods}

Results in Table 2 indicate willingness to take up snail farming as livelihoods. The respondents that had mean of above 2.0 agreed to choose snail production as livelihoods if they have the opportunity, they are also ready to obtain the training required in snail rearing. Despite the dampness, odour and crawling nature of snails, the respondents are still willing to choose the snail rearing. They were also ready to be committed to scouting for roots, leaves, vegetables and other materials in the wild that snail will require as feed.

Results illustrated in Figure 3 show the overall willingness of the snail consumers. Many (52\%) of the respondents were willing to choose snail production as livelihoods. The indication is that some of the snail consumers who do not want the snails to either be scares or not available will put an effort into producing it whenever they have the opportunity. 
Table 2: Willingness to choose snail production as livelihoods

\begin{tabular}{ll}
\hline Variables & Mean \\
\hline I will choose snail production as means of livelihoods if I am given the opportunity & 2.61 \\
I will create time to seek snail feed in the wild despite my present occupation & 2.56 \\
I will be willing to take training in snail rearing & 2.46 \\
I will cope with the odour and dampness of snailery & 2.45 \\
I can handle the crawling nature of snails and it will not affect my willingness to choose snail production. & 2.33 \\
I will still be able to operate snailery despite the slime produced by the snail & 1.62 \\
It is my responsibility to look for the market for the snail raised in order to grow the business & 1.55 \\
I will wait for eight to nine months to obtain more returns from snail enterprise & 1.54 \\
Regular use of chemical to fight the predators in snailery will not affect my willingness & 1.26 \\
\hline
\end{tabular}

\section{Perceived constraints to snail farming}

The constraints to snail farming as perceived by the respondents are listed in Table 3. Sourcing for the feed materials for the snail $($ mean $=1.64)$ was ranked first among other constraints. Akintomide (2004) opined that Giant African Snails are known to eat at least 500 different types of plants including peanuts, beans, cucumbers and melon. Snails can eat a wide variety of ornamental plants, the bark of tree, and even paint stucco on houses. (Akinnusi, 1998; Akintomide, 2004). How to obtain these feed materials are the concern that the consumers perceived they will likely face if they engage in snail farming since in their opinion the stuff might not be readily available.

Another constraint perceived was an inadequate skill in handling snail enterprise. If the respondents do not have the required knowledge and skills in the rearing of snail, it could lead to poor performance or lost in the snail business. It is important that the snail consumers who are willing to choose snail production as means of livelihoods should endeavour to acquire necessary basic skills in snail rearing before venturing into the livelihoods.

Yet another constraint perceived was inadequate skill in handling snail enterprise. If the respondents do not have the required knowledge and skills in the rearing of snail, it could lead to poor performance or lost in the snail business. Skills possessed by an individual enable them to use their ability to perform in an effective manner that will produce the desired outcome. Obi (2005) asserted that skill as manual dexterity is acquired through repetitive performance of operations.

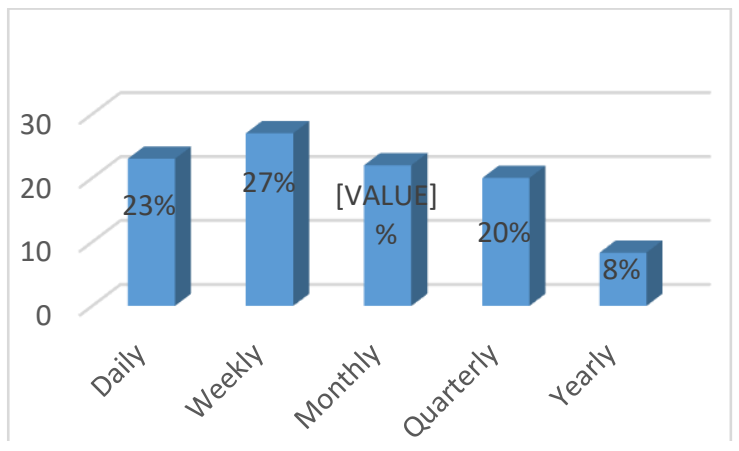

Figure 1: Snail consumption rate of the respondents in the study area

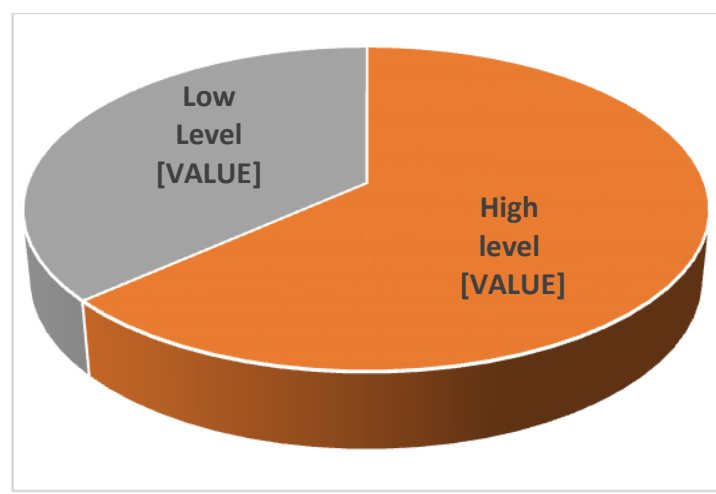

Figure 2: Categorization of snail consumption

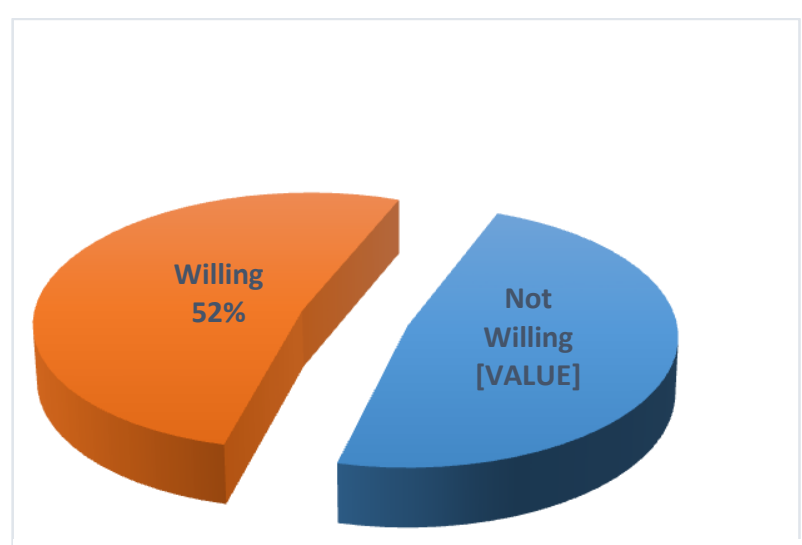

Figure 3: Categorization of snail consumers' willingness to choose snail production as livelihoods

Table 3: Perceived constraints to start-up a snail farm

\begin{tabular}{lcc}
\hline Constraints & Mean & Rank \\
\hline $\begin{array}{l}\text { Poor supply of feeding materials } \\
\text { for the snails }\end{array}$ & 1.64 & $1 \mathrm{st}$ \\
$\begin{array}{l}\text { Inadequate skill in snail rearing } \\
\begin{array}{l}\text { Insufficient capital to start up } \\
\text { the snail business }\end{array}\end{array}$ & 1.57 & $2^{\text {nd }}$ \\
$\begin{array}{l}\text { Pest and insect attack in snailery } \\
\begin{array}{l}\text { Climate change \& irregular } \\
\text { weather condition. }\end{array}\end{array}$ & 1.25 & $3^{\text {th }}$ \\
$\begin{array}{l}\text { Poor marketing channels for } \\
\text { the sale of snail }\end{array}$ & 1.23 & $5^{\text {th }}$ \\
$\begin{array}{l}\text { Slow turnover of the snailery } \\
\text { Pilfering and theft of snails }\end{array}$ & 1.17 & $6^{\text {th }}$ \\
\hline
\end{tabular}


Insufficient capital to start up the snail enterprise was ranked third by the respondents. This could probably because in their opinion a little amount of money cannot be used to start up the snail production. More so, much capital is needed if snail will have to be taken as livelihoods that can be commercialized. This concurred with the findings of Fowowe (2017) and Amentie et al. (2016) who opined that access to finance is essential for the growth of firms in the private sector, yet there is often a firm-financing gap in developing countries, particularly for small and new firms. The stealing of snail from snailery, possibility of slow turnover in snail business and a market for the snail were of less concern of the respondents, hence, they were ranked $8^{\text {th }}, 7^{\text {th }}$ and $6^{\text {th }}$ respectively. Nevertheless, they are still part of the constraints which must be addressed if the snail consumers will be willing to take up snail production as livelihoods.

\section{Test of hypotheses}

Results presented in Table 4 indicate that there is a significant relationship between socio-economic characteristics of the snail consumers and their willingness. The age is significant with $\mathrm{r}$-value of 0.346 at $p<0.01$. The implication is that as the respondents advance in age, their willingness to choose snail production as livelihoods increases. Positive significant relationship with the consumers' willingness to choose snail production as livelihoods, as the consumption level increases, their willingness also increases in the same direction. The interest of the people in the snail consumption could encourage them to be willing to rear the snail so as to sustain the supply of the snail for their consumption and as the case may be to sell the snails for money. The additional earnings from the snail enterprise will increase the household income and that could further encourage them to engage in snail rearing. The willingness to start up a snailery is of higher likelihood among the consumers than those that are not an eater of snails. This could be because snail rearing is not as tedious as other livestock production, and that makes aged snail consumers settle for snail rearing.

Table 4: Socio-economic characteristics as related to willingness for snail production as livelihoods

\begin{tabular}{lccc}
\hline Variable & $\mathrm{r}$ Value & $\mathrm{p}$ Value & Decision \\
\hline Age & $0.346^{* *}$ & 0.000 & $\mathrm{~S}$ \\
Household size & 0.149 & 0.112 & $\mathrm{NS}$ \\
Income & -0.324 & 0.016 & $\mathrm{~S}$ \\
\hline Note: S - Significant, NS - Not Significant &
\end{tabular}

Note: S - Significant, NS - Not Significant
Also, the income of the snail consumers was significant but it has an inverse relationship with their willingness. This means that as the income of the snail consumers' increases, their willingness to choose snail production as a means of livelihoods decreases. This means that low-income earners are more likely to make an attempt to go into snail rearing in order to make more income. Therefore, they tend to be ready and willing to choose snail rearing as a means of live livelihood.

There was a significant positive relationship between consumers' level of consumption and their willingness to choose snail production as livelihood $(r=0.200, p<0.05)$. As the consumption level increases, consumers' willingness increases. Their interest in snail consumption makes them willing to rear snail for both consumption and selling to make money. This extra household income could lure them into snail rearing. The willingness to start up snailery is of higher likelihood among the consumers than non-consumers of snails.

\section{CONCLUSION}

The snail consumers were mainly male, young, married with a mean household size of 6 persons. Many of them eat snail weekly and their overall level of consumption was high which suggest the reason for the willingness of more than half of the studied population to start up snail farming. The study concludes that the age, income and level of consumption of the snail consumers are important influencing factors which could determine their willingness to choose snail farming as a livelihood. The more the consumers eat the snail, the better their likelihood to choose snail rearing as a means of livelihood. It is therefore recommended that interventions for snail production should be packaged for the young and high snail consumers by the government, agricultural agencies and funders. The interventions should endeavour to resolve constraints that the snail consumers perceived that can hinder the snail enterprises if they eventually engage in snail production. The effort will encourage people who are willing to choose snail production as a livelihood thereby resolving the decrease in the number of snails in the wild due environmental stress and threat.

\section{REFERENCES}

Akinnusi O. (1998). Introduction to Snail Farming. Omega Publishers, Lagos, Nigeria

Akintomide I.A. (2004). Tropical Snail Farming. Oak Ventures Publishers, Lagos, Nigeria. pp. 5-6

Amentie C., Negash E. and Kumera L. (2016). Barriers to growth of medium and small enterprises in developing country: case study Ethiopia. Journal of Entrepreneurship and Organization Management, 5, 190. doi:10.4172/2169-026X.100019 
Aristotle University of Thessaloniki (2013). Feasibility study for snail breeding units (2013). [https://touchstonesnailfranchise.com/snail-market/]

Bonomo É., Caiaffa W.T., César C.C., Lopes A.C.S. and Lima-Costa M.F. (2003). Food intake according to socioeconomic and demographic profile: the Bambui Project. Cad Saúde Pública, 19, 1461-1147

Cobbinah J.R., Vink A. and Onwuka B. (2008). Snail farming: Production, Processing and Marketing. $\left(1^{\text {st }}\right.$ ed.), Agrodok 47. Agromisa foundation. Wageningen ISBN CTA 978-92-9081 398-9

Ebenso I. E. (2003). Dietary calcium supplement for edible tropical land snail Archachatina marginata in Niger Delta, Nigeria. Livestock Res. Rural Dev., 15, 52-56

Ejidike B.N., Afolayan T.A. and Alokan J.A. (2004). Observations on some climatic variables and dietary influence on the performance of cultivated African giant land snail (Archachatina marginata): notes and records. Parkistan Journal of Nutrition 3, 362-364

Figueiredo I.C.R., Jaime P.C. and Monteiro C.A. (2008). Factors associated with the consumption of fruits and vegetables in adults in the city of São Paulo. Rev Saúde Pública, 200, 42, 77-85

Fowowe B. (2017). Access to finance and firm performance: Evidence from African countries. Review of Development Finance, 7, 6-17

Kehinde A.S., Tewe O.O., Babatunde T.O. and Babadoye O.A. (2009). Effect of age on chemical composition and carcass analysis of African giant land snail (Archachatina marginata). Journal of Forestry Research and Management, 16, 41-47

Kiefer I., Rathmanner T. and Kunze M. (2005). Eating and dieting differences in men and women. The Journal of Men's Health \& Gender, 2(2), 194-201

Lawal J.O. and Oluyole K.A. (2008). Factors influencing adoption of research results and agricultural technologies among cocoa farming households in Oyo State, Nigeria. International Journal of Sustainable Crop Production, 3 (5), 10-12
Murphy B. (2001). Breeding and growing snails commercially in Australia. A report for the Rural Industries Research and Development Corporation. RIRDC Project No. ARH-1A. RIRDC Publication No. $00 / 188$

Ngenwi A.A., Mafeni J.M., Etchu K.A. and Oben F.T. (2010). Characteristics of snail farmers and constraints to increased production in West Africa, African Journal of Environmental Science and Technology, 4, 274-278

Obi C.A. (2005). Methodology in Business Education. Enugu, Oktek Publishers Nigeria Ltd.

Olaleye D.A. (2013). Consumers' preferences for snail meat in the Africa Community of Pittsburgh, Pennsylvania. A Research Paper Presented for the Master of Science in Agriculture and Natural Resources, the University of Tennessee at Martin

Omole A.J., Osunkeye O.J., Odejide J.O., Sodamola M.O.and Popoola Y.A. (2011). The African Giant Land Snail. Green Choice Agricultural Publication. pp. 56-60

Parternostro M. and Ide E. (2015). Snail caviar a slimy delight for Sicilian startup. The Daily Star (Lebanon) p. 1,4

Prattala R., Paalanen L., Grinberga D., Helasoja V., Kasmel A. and Petkeviciene J. (2006). Gender differences in the consumption of meat, fruit and vegetables are similar in Finland and the Baltic countries. The European Journal of Public Health, 17 (5), 520-525

Pyron M. and Brown K.M. (2015). Introduction to mollusca and the class Gastropoda. Elsevier Inc. doi: org/10.1016/B978-0-12-385026-3.00018-8

Strong E.E., Gargominy O., Ponder W.F. and Bouchet P. (2008). Global diversity of gastropods (Gastropoda; Mollusca) in freshwater. Hydrobiologia, 595, 149-166

Tremlova B. (2001). Histological examination of snail meat specialities. Fleischwirtschaft, 81 (12), 96-97 